\title{
The specifics of retail network's spatial structure in the city of Žilina
}

\author{
Miroslava TREMBOŠOVÁ, Alena DUBCOVÁ, Michaela ŠTUBŇOVÁ
}

\begin{abstract}
The retail network as a variable subsystem of a cultural landscape is an important feature of the settlement system and the inner structure of the settlements. In the urban environment of post-socialist countries under the influence of globalization the retail network belongs to the most dynamic elements. Our goal is to identify the spatial configuration of demographic and retail indicators. Data obtained from field passportization were processed by using statistical-mathematical methods. We also deal with the processes and specifics of the retail network of the city of Žilina, which impact on the modeling of its spatial structure, polycentrism, increase of disparities and commercial suburbanization. The development of the retail network in the city of Žilina is significantly influenced by the following factors: purchasing power of residents, globalization impacts of supranational retail chains'entrance, accessibility, synergy effect, development of new retail forms, and self-government policies. The paper is part of a broader research into the retail network of large cities in Slovakia. The research has been carried out with the same methodology as in the two regional cities of Nitra and Trnava. The automotive industry as an important economic factor is the common feature of all of them.
\end{abstract}

Keywords: retail network, city of Žilina, size parameter, sales area saturation index, parameter of inhabitants' number/l store, synthetic parameter

\section{Introduction}

Among the anticipated trends of the $21^{\text {st }}$ century are, besides technological, climate and socio-demographic changes, also changes in spatial development, caused by a change in the behavior of residents in spending their free time, shopping, beauty salons, special healthy services, traveling for work and others. Future cities will be networked, represented by shortened material and organizational distances.

These conditions also determine the new nature of retail sales processes, affecting retail networks at different speeds and at different levels. The consumer has much more choice between different purchase options (even the same types of goods), decides what, where and how he wants to buy (internet-based versus brick and mortar retail store). The qualitative aspects of the consumer decision-making process, such as the prioritizing the quality of goods, the level of customer service over price, the quality and speed of service etc., are becoming increasingly prominent. In the competitive struggle, in particular retailers, who run small-scale as well as large-scale brick and mortar stores, are forced to continually improve the quality of their sales services, modify existing offers and create new business formats to reflect and adapt to changing consumer demands. They are introducing new technologies that are now starting to play a significant role. The retail network is very sensitive to changes in the social and economic situation of consumers.

DOI: https://doi.org/10.33542/GC2019-2-07 
The aim of the paper is to point out the specifics of retailing structures, to evaluate the level of retail network in the city of Žilina and its city boroughs (further CB) according to the approved parameters of the retail network, to point out places with surplus or scarcity of retail entities in relation to the number of inhabitants and their sales area. Analysis material consists of a database obtained by a field passportisation of retail facilities (location description, structure and sales area). Methodologically, we used the information resulting from a detailed passportisation of statistically unavailable data (number and assortment structure of stores as well as their sales area) to identify groups of city boroughs with a similar structure of these data and population. For their comparison, we used: (i) sales area saturation index $\mathrm{m}^{2} / 1,000$ inhabitans (internationally referred to as PAFS parameter (the Population to the Admissible Floor Space indicator)), (ii) size parameter (store's sales area in $\mathrm{m}^{2} / 1$ store), (iii) parameter of inhabitants' number/1store, (iv) synthetic parameter on level of city boroughs.

Our aim is to confirm or refuse the assumption that the sales area in urban areas depends on the number of inhabitants and the number of stores. The hypothesis is based on the knowledge of the retail network of so far investigated regional cities Nitra and Trnava, where the linear regression dependence of the sales area on the number of inhabitants of urban parts was confirmed, on the other side the dependence of the sales area and the number of stores was not confirmed (Trembošová et al. 2016).

\section{Theoretical Framework}

Recent research on brick and mortar retail stores by Bäckström and Johansson (2017) suggests how the role of this type of store has changed over the past decade. Interestingly, the results are in great extent the same as ten years ago (e.g. staff, layout, atmosphere). Although retailers today emphasize the importance of meeting new and more advanced consumer requirements, they often prefered the traditional values (such as staff and scheduling) over advanced technologies. According to Amcoff (2016), specialized consumer durable retail stores have left the city centers and located mainly in their outskirts. There are also indications that the customer base needed to make a profit in business has increased. These findings correspond to the already published conclusions in the field of retail geography in polycentric cities e.g. in Brno (Bednáŕ 2005 and Mulíček 2007), in Olomouc (Szcyrba 2001), in Nitra (Pulpitlová 2005 and Trembošová 2009), Košice and Prešov (Mitríková 2008). The growth and development of the retail network outside the city, which is a sign of restructuring forces, is confirmed by the collective work of Kunc et al. (2012).

The localization of large retail chains has gained the attention of professionals only when there has been a rapid depopulation of live urban centers (Nagy 1999), a process of decentralization (Guy 1998, Wrigley and Lowe 2002), moving shopping centers to satellite and outskirt areas (Drzog 2004, Florian, Schwarz and Zcilincsar 2005, Alexander 2009, Maryas et al. 2014, Križan et al. 2016).

From the American urban environment characterized by large areas and long distances, comes the phenomenon of "food desert", e.g. Wrigley, Warm and Margetts (2003), which was followed by European and Asian researchers, e.g. Križan and Danielová (2008), Suchý (2010), Choi and Suzuki (2013), Bilková and Križan (2015). After years of growth in shopping centres, studies on the resilience of shopping centres are emerging from potential failures and loss of their viability (Guimarães 2018). These processes were already reflected in 2012 by Kunc et al., when he emphasized that consumers in Central Europe are turning away from shopping in supermarkets and favoring smaller and more accessible shops in their vicinity.

Retailing in countries of western Europe is a subject to significant regulation. The adoption of restrictive measures in the retail sector began in the OECD countries (Pilat 1997, Ennis 2008), in France even in the early 1970s (Bertrand and Kramarz 2002) and in the 1990s in 
Britain (Griffith and Harmgart 2008, Haskel and Sadun 2009). Employment is one of the reasons for strong regulation in these European countries, as the retail sector employs approximately $10 \%$ of the workforce in all industrialized economies (Schivardi and Viviano 2011).

The effects of regulation were analyzed e.g. from 1997 to 2003 in the United Kingdom by Haskel and Sadun (2009). They investigated the consequences of limiting the entry of large stores to the outskirts of cities, as well as the opposite efforts to open smaller businesses in the city centers, albeit with adverse economic results. Thus, regulation helps small, uncross-linked businesses (Baar 2002, Schivardi and Viviano 2011).

The development of the retail network and the adoption of regulatory measures in the countries of Central and Eastern Europe (CEE) are examined by several authors, mainly abroad, e.g. Sýkora (1999), Nagy (1999b), Borén and Gentile (2007), Pojani (2011), Spilková and Šefrna (2011), Cvetinović and Veselinović (2014), Tsenkova (2014), Maksić (2016) and Hlaváček, Raška and Balej (2016).

Considerable attention is paid to the investigation of the location and attractiveness of shops in relation to pedestrian accessibility (especially in centralized parts of the city), as well as the accessibility by public transport or a car in the outskirts of cities, where new shopping centers and parks were created due to commercial suburbanization. In the first periods of their formation, the aspect of free and cheap areas was coming to the foreground, not paying much attention to ensuring sufficient customers for new retail facilities (Trembošová and Tremboš 2009). In particular, investors and large multinational retail chains use the experience gained from building modern retail "megacenters" in countries of different sizes, different levels of development and different cultures, or they can also hold the popular view that "the hand of the market" will shatter them in the territory.

Urbanists and geographers have traditionally preferred retail as a key measure of urban vitality and the city center's dominant position in the urban hierarchy (Hillier 1999). The concept of "living center" is the core topic of Hillier's theory of centrality as a process that states that pedestrian movement patterns are influenced by the urban border network, leading to creation of networks of interconnected centers with retail and other services. Research by Vaughan et al. (2010) focused on the suburban centers of Great London questioned the theory of the predominant retail function by suggesting that the sources of vitality at local sites will be based on diverse socio-economic and cultural activities taking place outside the main shopping center. The author asks: "How does shopping depend on a sample of pedestrian movement, what kind of spatially comparable features of the urban street network predetermines the location of the shops?" Even from earlier research (Hillier 1999, p. 110-113) it was found that shops tend to localize along the most spatially integrated streets and streets with a high level of connectivity.

\section{Methodology and data}

In urban settlements, retail amenities form an essential and inseparable part of the spatial structure of the public amenities network. The basic unit of the retail network is the store. The data were obtained by authors'detailed field research of each retail store. The field research from June to September 2015 identified 952 retail stores in the city of Žilina and its 20 city boroughs (hereafter CBs). They were grouped using 4 rules: i) according to the range of goods (17 groups of related goods), ii) according to the store's sales area (small-scale up to $400 \mathrm{~m}^{2}$ and large-scale), iii) according to the business model (specialized and universal) and iv) according to the condition of the goods (new goods stores and secondhand goods stores, e.g. secondhand shops, antiques, secondhand bookshops, bazaars). Using hierarchical cluster analysis, we identified groups of CBs with a similar population structure, number of retail stores and store's sales area in $\mathrm{m}^{2}$. We used the Euclidean distance as a measure of the distance between individual objects (CBs): 


$$
d_{i j}=\sqrt{\sum_{k=1}^{p}\left(x_{i k}-x_{j k}\right)^{2}}
$$

where $p$ is a number of indicators measured on objects and $x_{i k}$, respectively $x_{j k}$ is a value of $k$-th indicator of $i$-th, respectively $j$-th object (Vrábelová 2013).

Based on the calculated distances, we divided the CBs into clusters using three agglomerative hierarchical clustering methods - Single Linkage, Complete Linkage, Ward's method. Agglomerative methods start with each object being its own cluster, at every step the most similar clusters (with the smallest distance) are merged to form a new cluster. The optimal number of clusters is determined by a heuristic approach. The Single Linkage method defines the distance of two clusters as the distance of two objects from these clusters that are closest to each other. On the contrary, the Complete Linkage method defines this distance as the distance between the two most distant objects. Ward's method uses analysis of variance. The pair of clusters is merged if this merger results in a minimum increase in total within-cluster variance. The process of merging the individual CBs into clusters is graphically represented by the hierarchical classification tree - dendrogram. Calculations were performed in Statistica 13.

In the resulting clusters, we used the correlation analysis to examine the strength of association between indicators describing the CBs. In order to measure the strength and direction of the statistical dependence between the store's sales area in $\mathrm{m}^{2}(X)$ and the linear combination of the number of retail stores $(Y)$ and the number of inhabitants $(Z)$ in the individual CBs of Žilina, we used the sample multiple correlation coefficient $r_{X(Y, Z)}$, which is obtained by calculating the square root of $r_{X,(Y, Z)}^{2}$ :

$$
\begin{gathered}
r_{X,(Y, Z)}^{2}=\frac{r_{X, Y}^{2}-2 r_{X, Y} \cdot r_{X, Z} \cdot r_{Y, Z}+r_{X, Z}^{2}}{1-r_{Y, Z}^{2}}, \\
\text { where } r_{X, Y}=\frac{\sum_{i=1}^{n} X_{i} Y_{i}-n \bar{X} \bar{Y}}{\sqrt{\sum_{i=1}^{n} X_{i}^{2}-n \bar{X}^{2}} \cdot \sqrt{\sum_{i=1}^{n} Y_{i}^{2}-n \bar{Y}^{2}}}, r_{X, Z}=\frac{\sum_{i=1}^{n} X_{i} Z_{i}-n \bar{X} \bar{Z}}{\sqrt{\sum_{i=1}^{n} X_{i}^{2}-n \bar{X}^{2}} \cdot \sqrt{\sum_{i=1}^{n} Z_{i}^{2}-n \bar{Z}^{2}}}, \\
r_{Y, Z}=\frac{\sum_{i=1}^{n} Y_{i} Z_{i}-n \bar{Y} \bar{Z}}{\sqrt{\sum_{i=1}^{n} Y_{i}^{2}-n \bar{Y}^{2}} \cdot \sqrt{\sum_{i=1}^{n} Z_{i}^{2}-n \bar{Z}^{2}}},
\end{gathered}
$$

$n$ is number of observations, $\bar{X}, \bar{Y}$ and $\bar{Z}$ average values of indicators $X, Y$ and $Z$ (Markechová et al. 2011).

We also measured the degree of the association between the store's sales area and individual indicator after eliminating the impact of the second indicator. The measure of such a correlation is the sample partial correlation coefficient. According to Markechová et al. (2011) the sample partial correlation coefficient between indicator $X$ and $Y$ after eliminating the impact indicator $Z$ is given by $r_{X, Y \cdot Z}$ :

$$
r_{X, Y \cdot Z}=\frac{r_{X, Y}-r_{X, Z} \cdot r_{Y, Z}}{\sqrt{\left(1-r_{X, Z}^{2}\right) \cdot\left(1-r_{Y, Z}^{2}\right)}}
$$

The sample partial correlation coefficient between indicators $X$ and $Z$ after eliminating the impact of indicator $Y$ is given by $r_{X, Z \cdot Y}$ :

$$
r_{X, Z \cdot Y}=\frac{r_{X, Z}-r_{X, Y} \cdot r_{Z, Y}}{\sqrt{\left(1-r_{X, Y}^{2}\right) \cdot\left(1-r_{Z, Y}^{2}\right)}} .
$$


Using cluster analysis, we identified 3 clusters of CBs of Žilina that had a similar retail network structure and number of inhabitants. For all the grouping methods we used, we obtained identical clusters. In the $1^{\text {st }}$ cluster was included only CB Staré Mesto, in the $2^{\text {nd }}$ cluster were included CBs Vlčince, Solinky and Hliny, in the $3^{\text {rd }}$ cluster were included CBs Hájik, Bytčica, Rosinky, Závodie, Strážov, Považský Chlmec, Bôrik, Trnové, Zástranie, Zádubnie, Vranie, Žilinská Lehota, Mojšová Lúčka, Brodno, Budatín and Bánová. We identified the level (very low, low, average, high and very high) of retail amenities of CBs in the individual clusters using a synthetic assessment of the sales area saturation index (store's sales area in $\mathrm{m}^{2} / 1,000$ inhabitants), size parameter (store's sales area in $\mathrm{m}^{2} / 1$ store) and parameter number of inhabitants/1 store.

According to the standards of minimum amenities (Vitková et al. 2001) for the Slovak cities with the size of Žilina has a saturation of retail amenities the value $800 \mathrm{~m}^{2} / 1,000$ inhabitants and for foreign countries from 750 to 2,500 $\mathrm{m}^{2} / 1,000$ inhabitants. Szczyrba (2005) states that for EU cities set a standard is $1,000 \mathrm{~m}^{2}$ of sales area per 1,000 inhabitants. The city of Žilina, which reaches $1,443 \mathrm{~m}^{2}$ of sales area / 1,000 inhabitants, exceeds this indicator. Subsequently, there was estimated a "surplus" or "scarcity" of retail stores and their sales area in the CBs according to the surplus concentration index $\left(I_{C S}\right)$ based on the Očovský (1976) retail turnover index and used and taken from Bilková and Križan (2013).

By analyzing the relationship between the number of inhabitants and the number of stores (and the sales area) in the individual CBs compared to the city, the CBs can be divided into two groups. The first group of "surplus" consists of CBs with above-average retail amenities, which appertain them due to the number of inhabitants and the average of the city. The second group is "scarce", which is formed by the CBs with a below-average retail network, which should be achieved with respect to the number of inhabitants and the city average.

For quantification of "surpluses", a theoretical number of stores (TP) and a theoretical number of sales area (TPP) linked to the number of inhabitants in the $\mathrm{CB}$ were introduced for each CB:

$$
T P=P_{i} \cdot S
$$

where $P_{i}$ is the number of inhabitants in the $i$-th $\mathrm{CB}$ and $S$ is the average number of stores (sales area) in Žilina. By comparing the actual and theoretical value of the number of stores (sales area), it is possible to obtain an indication of the size of the "surplus" or " scarcity" of the number of stores (sales area) in the $i$-th CB. The surplus (scarcity) concentration index is in the form of:

$$
I_{C S}=\frac{S_{i}-P_{i} \frac{S}{P}}{S_{i} \cdot 100},
$$

where $S_{i}$ is the number of retail stores (sales area) in the $i$-th $\mathrm{CB}, S$ is the number of retail stores (sales area) of the city and, by analogy, $P_{i}$ is the number of inhabitants in the $i$-th $\mathrm{CB}$ and $P$ is the population of the city (the year 2015).

\section{The city of Žilina and the assortment structure of its retail network}

The regional capital city of Žilina is the fourth largest city of Slovakia with an area of 80,03 $\mathrm{km}^{2}$, with a population of 80,810 (the year 2018) and a population density of 1,050 inhabitants per $\mathrm{km}^{2}$, which is above-average population density in Slovakia (111 inhabitants $/ \mathrm{km}^{2}$ ).

The location of the city in the Žilina Basin allows it to grow what is strengthened by the traffic position at the intersection of road and railway thoroughfare (railway 180, motorways D1, D3). The basis of the city's road transport is the city ring around the center. The roads 
continue in the direction of the current main roads of the I. and II. classes that merge to higher classes of international importance - the E50, E75, E442 and the D1 and D3 motorways.

In the city of Žilina, 952 brick and mortar retail stores were identified, which offered goods on $120,623 \mathrm{~m}^{2}$ of sales area. Retail network saturation reaches $1,443 \mathrm{~m}^{2}$ of sales area per 1,000 inhabitants. The average sales area per one store is $126 \mathrm{~m}^{2}$ and the service reaches 88 inhabitants per one store.

As a regional capital, Žilina is a center of supra-regional importance, characterized by a diverse structure of retail stores. Out of the 17 assortment groups, stores with textiles, clothing, and footwear have a dominant position in the number of stores and they have been operating on a sales area of $32,650 \mathrm{~m}^{2}$ (Table 1). The average store's sales area is $148 \mathrm{~m}^{2}$. The second largest group is the food, beverage and tobacco stores with $26,412 \mathrm{~m}^{2}$ of sales area, mainly made up of foreign chains Billa, Lidl, and Kaufland. Both groups concentrate more than two fifths $(41.6 \%)$ of the retail network and $48.9 \%$ of the retail sales area.

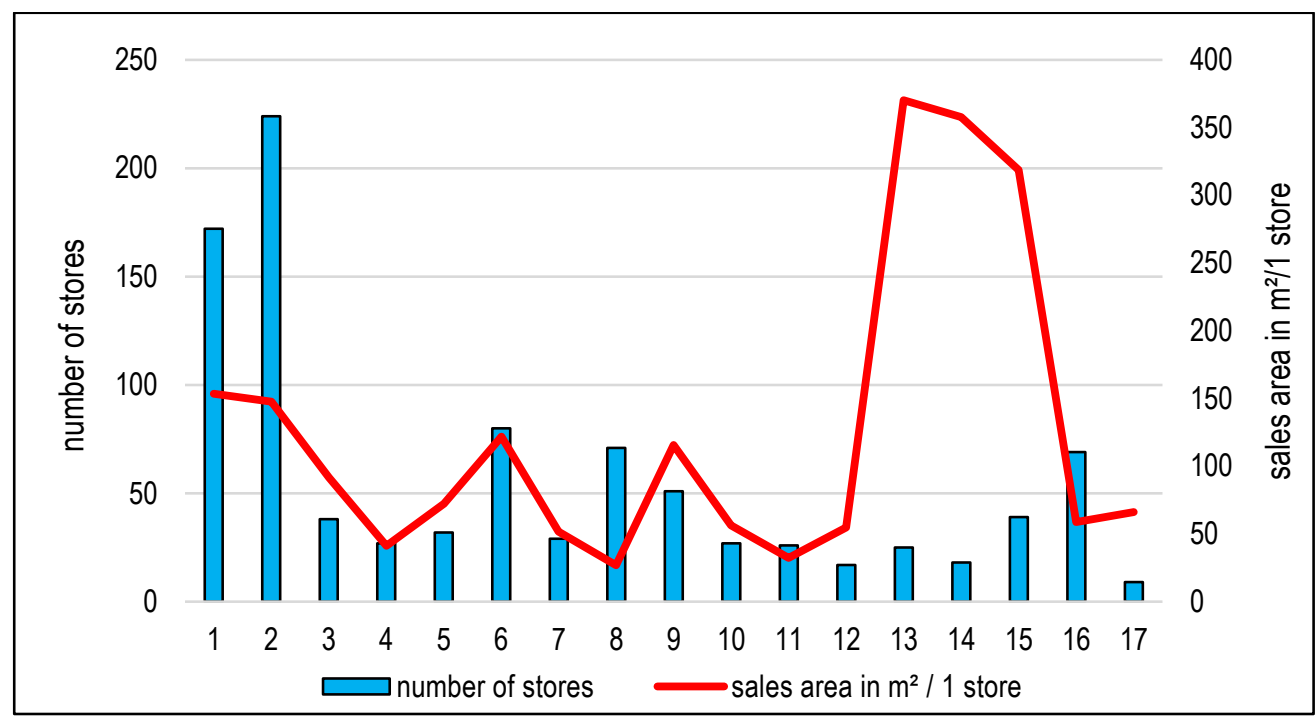

Figure 1. Number of stores and sales area in $\mathrm{m}^{2} / 1$ store of retail stores based on assortment groups in Žilina in 2015

Note: 1 - 17 - types of retail store based on assortment groups (see Table 1)

Goldsmiths have a surprisingly high representation in comparison with Nitra and Trnava, which reflects both the higher purchasing power of the population due to the automotive industry and the reflection of the trade tradition (The Golden Way). The entire group, together with jewelry, watchmaking, and optics, accounted for up to $7.5 \%$ of retail stores. These are mainly smaller stores that provide customers with a sales area of $1,912 \mathrm{~m}^{2}$. The category of pharmacies and health care stores also has the higher number of stores with a sales area of $1,111 \mathrm{~m}^{2}$. Given the aging population and the associated demand for medicines and medical devices, their number are likely to grow.

Car dealerships and construction goods are characterized by a larger sales area for the presentation of goods, such as cars of different brands, construction products, etc. Their average sales area per one store exceeds $300 \mathrm{~m}^{2}$ (Figure 1). This group also includes petrol stations in 18 locations with a sales area of $6,439 \mathrm{~m}^{2}$. The low number of mixed stores confirms the retail lifecycle concept, according to which they are in the decline phase (Szczyrba 2005, Križan 2009, Mitríková 2017). 
Table 1. The assortment structure and its indicators in the city of Žilina in 2015

\begin{tabular}{|c|c|c|c|c|c|c|}
\hline & \multirow[t]{2}{*}{ type of store } & \multicolumn{2}{|c|}{$\begin{array}{c}\text { number of } \\
\text { stores }\end{array}$} & \multicolumn{2}{|c|}{ sales area in $\mathrm{m}^{2}$} & \multirow{2}{*}{$\begin{array}{c}\text { sales } \\
\text { area in } \\
\mathrm{m}^{2} / 1 \\
\text { store }\end{array}$} \\
\hline & & abs. & $\%$ & abs. & $\%$ & \\
\hline 1 & food, beverage and tobacco stores & 172 & 18.1 & 26,412 & 21.9 & 153.6 \\
\hline 2 & stores with textiles, clothing, and footwear & 224 & 23.5 & 32,650 & 27.0 & 147.8 \\
\hline 3 & stores with drugstore goods, paints, varnishes, and cosmetics & 38 & 4.0 & 3,481 & 2.9 & 91.6 \\
\hline 4 & pharmacies and health care stores & 27 & 2.8 & 1,111 & 0.9 & 41.1 \\
\hline 5 & stores with toys and sporting goods & 32 & 3.3 & 2,311 & 1.9 & 72.2 \\
\hline 6 & stores with furniture and home accessories & 80 & 8.4 & 9,272 & 7.7 & 121.8 \\
\hline 7 & stores with flowers and gardening supplies & 29 & 3.0 & 1,496 & 1.2 & 51.6 \\
\hline 8 & goldsmiths, jewelry, watchmaking, and optics & 71 & 7.5 & 1,912 & 1.6 & 26.9 \\
\hline 9 & electronics, electrical and music stores & 51 & 5.4 & 5,896 & 4.9 & 115.6 \\
\hline 10 & stationery, office supplies, and bookstores & 27 & 2.8 & 1,522 & 1,3 & 56.4 \\
\hline 11 & glass-porcelain stores, gift shops & 26 & 2.7 & 837 & 0.7 & 32.2 \\
\hline 12 & breeding shops & 17 & 1.8 & 934 & 0.8 & 54.9 \\
\hline 13 & car dealerships & 25 & 2.6 & 9,255 & 7.7 & 370.2 \\
\hline 14 & fuel stores & 18 & 1.9 & 6,439 & 5.3 & 357.7 \\
\hline 15 & construction goods stores & 39 & 4.0 & 12,431 & 10.3 & 318.7 \\
\hline 16 & industrial goods stores, hardware stores & 69 & 7.2 & 4,068 & 3.4 & 58.9 \\
\hline \multirow[t]{2}{*}{17} & mixed goods stores & 9 & 0.9 & 596 & 0.5 & 66.2 \\
\hline & city of Žilina & 952 & 100 & 120,623 & 100 & 126.7 \\
\hline
\end{tabular}

Source: field research, 2015

Based on the size of the store's sales area, stores can be divided into two groups. Smallscale stores - self-operating with a sales area of up to $400 \mathrm{~m}^{2}$, there are 661 of them in Žilina (without stores in the shopping centers further SC and similarly shopping entertainment centers further SEC) and large-scale stores with a sales area over $400 \mathrm{~m}^{2}$, there are 57 of them. The shopping centers are characterized by large sales area - SC Aupark, SC Mirage, SC Dubeň and SEC Max (Tab. 2). 234 retail units were operating in these shopping centers, which use $23,319 \mathrm{~m}^{2}$ of sales area - almost one fifth $(19.33 \%)$ of the city's sales area. Shopping center's GLA was 46,600 $\mathrm{m}^{2}$ (2015).

Table 2. Shopping centers of Žilina

\begin{tabular}{l|l|r|r|r|r|r}
\hline Shopping center & $\begin{array}{c}\text { city } \\
\text { borough }\end{array}$ & $\begin{array}{c}\text { year of } \\
\text { opening }\end{array}$ & $\begin{array}{c}\text { number } \\
\text { of stores }\end{array}$ & sales area* & parking spots & $\begin{array}{c}\text { GLA (gross } \\
\text { leasable area) }\end{array}$ \\
\hline Atrium Dubeň & Vlčince & 2001 & 55 & 7,452 & 1,080 & 22,600 \\
Max & Solinky & 2009 & 43 & 7,757 & 490 & 25,431 \\
Aupark & Staré Mesto & 2010 & 86 & 4,955 & 850 & 24,000 \\
Mirage & Staré Mesto & 2010 & 50 & 3,155 & 388 & 25,671 \\
\hline city of Žilina & & & $\mathbf{2 3 4}$ & $\mathbf{2 3 , 3 1 9}$ & $\mathbf{2 , 8 0 8}$ & $\mathbf{4 6 , 6 0 0}$ \\
\hline
\end{tabular}

Source: OC ATRIUM DUBEŇ ŽILINA (2016), ZOC MAX ŽILINA (2016), OC MIRAGE ŽILINA (2016), OC AUPARK ŽILINA (2016)

Parking lots with a total capacity of 2,808 parking spots are available for customers in shopping centers. Shopping centers (Figure 2) are characterized by a grouping of different kinds of different stores under one roof and are universal sales units. Another type is specialized large-scale stores to which we include subjects such as Nay Elektrodom (electronics) as well as supermarkets (e.g. Billa, Lidl) and hypermarkets (e.g. Kaufland). Food chain stores e.g. Billa, Lidl, and Kaufland, represent the concentration of the food retail offer in Žilina, localized both separately and in shopping centers. 


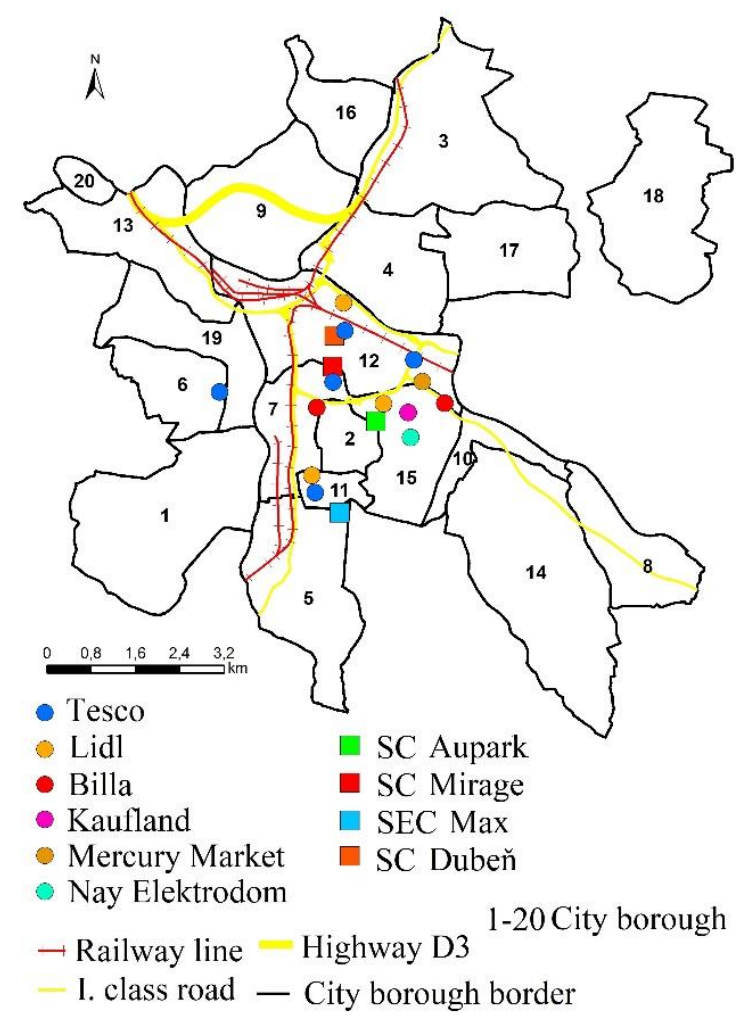

Figure 2. Location of retail stores with sales area above $2,500 \mathrm{~m}^{2}$

City boroughs by numbers: 1 - Bánová, 2 - Bôrik, 3 -Brodno, 4-Budatín, 5 -Bytčica, 6 Hájik, 7 - Hliny, 8 - Mojšova Lúčka, 9 - Považský Chlmec, 10 - Rosinky, 11 - Solinky, 12 Staré Mesto, 13 - Strážov, 14 - Trnové, 15 -Vlčince, 16 -Vranie, 17 -Zádubnie, 18 -Zástranie, 19 - Závodie, 20 - Žilinská Lehota;

SC - shopping centre, SEC - shopping and entertainment centre

In addition to stores with new goods, we know the stores with the used ones. Of all 952 retail stores, up to $98.9 \%$ (939) sold new goods. Used goods stores include antiques (4 stores, $260 \mathrm{~m}^{2}$ ), secondhands ( 8 stores, $721 \mathrm{~m}^{2}$ of sales area) and 1 secondhand bookshop $\left(25 \mathrm{~m}^{2}\right)$. At present, they are characterized by a stable position in the retail amenities of Žilina.

\section{Spatial structure of the retail network of CBs of Žilina}

There are localized stores of different quality in every CBs of the city of Žilina. Using cluster analysis, we identified 3 clusters of CBs of Žilina that have a similar retail network structure and number of inhabitants. For all the grouping methods we used, we obtained identical clusters. Their graphic outputs are shown in Figure 3. In the $1^{\text {st }}$ cluster was included only CB Staré Mesto, in the $2^{\text {nd }}$ cluster were included CBs Vlčince, Solinky, and Hliny, in the $3^{\text {rd }}$ cluster were included CBs Hájik, Bytčica, Rosinky, Závodie, Strážov, Považský Chlmec, Bôrik, Trnové, Zástranie, Zádubnie, Vranie, Žilinská Lehota, Mojšová Lúčka, Brodno, Budatín and Bánová.

It is clear from Tab. 3 that CBs with similar features were merged into clusters. The first cluster is formed by CB Stare Mesto, which is the center of Žilina. However, the number of inhabitants is smaller than in the residential CBs. There is the densest network of retail stores with a total sales area of $51,823 \mathrm{~m}^{2}$, while the average value of this indicator is only $6,031 \mathrm{~m}^{2}$. It concentrates nearly $60 \%$ of the city's retail units. 

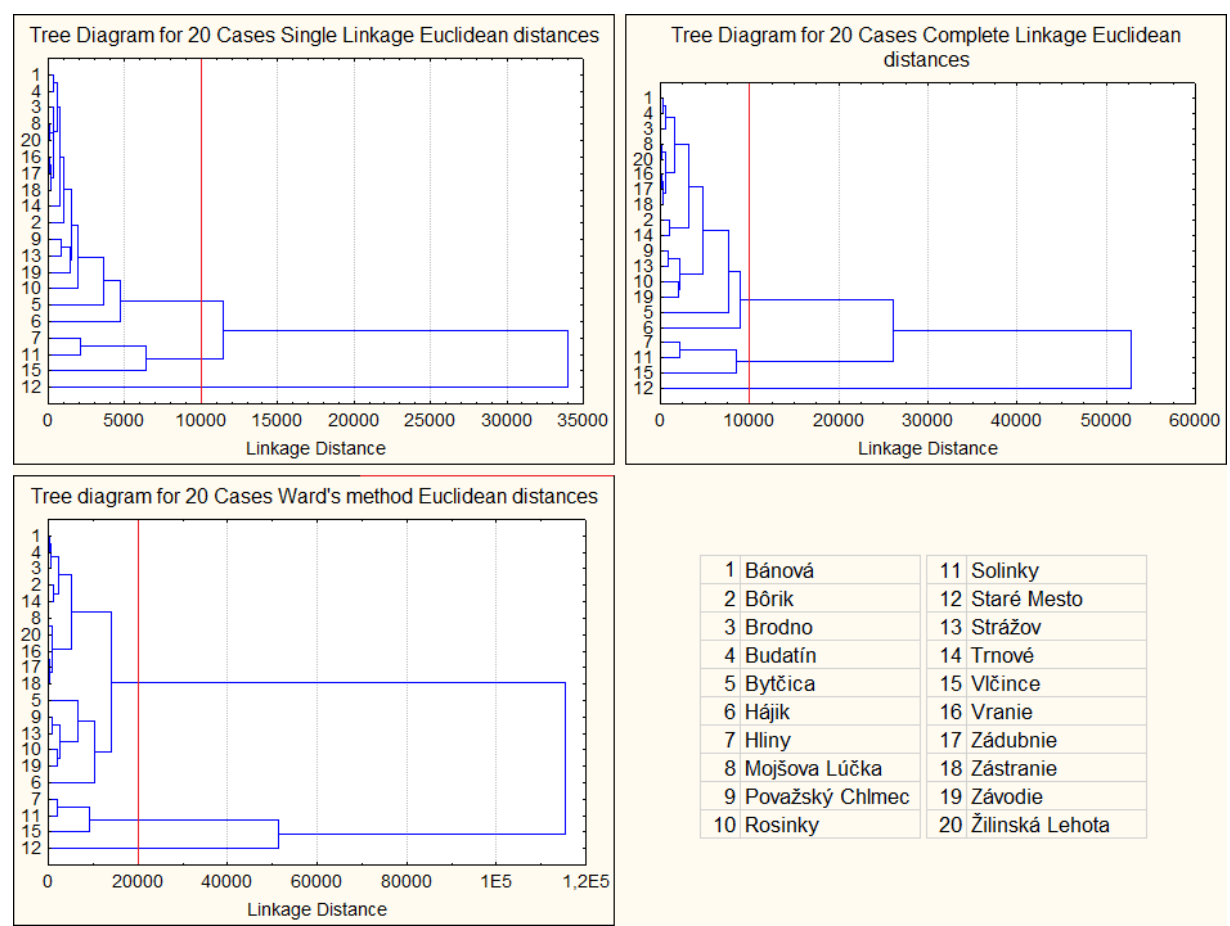

\begin{tabular}{|l||l|}
\hline 1 Bánová & 11 Solinky \\
\hline 2 Bôrik & 12 Staré Mesto \\
\hline 3 Brodno & 13 Strážov \\
\hline 4 Budatín & 14 Trnové \\
\hline 5 Bytčica & 15 Vlčince \\
\hline 6 Hájik & 16 Vranie \\
\hline 7 Hliny & 17 Zádubnie \\
\hline 8 Mojšova Lúčka & 18 Zástranie \\
\hline 9 Považský Chlmec & 19 Závodie \\
\hline 10 Rosinky & 20 Žilinská Lehota \\
\hline
\end{tabular}

Figure 3. Graphical output of cluster analysis; Source: field research, compiled by authors

Table 3. Cluster analysis results and characteristics of selected retail indicators of CBs of Žilina (the year 2015)

\begin{tabular}{|c|c|c|c|c|c|c|c|c|c|}
\hline $\begin{array}{c}\text { city } \\
\text { borough }\end{array}$ & $\begin{array}{c}\text { number of } \\
\text { inhabit- } \\
\text { ants }\end{array}$ & $\begin{array}{l}\text { number } \\
\text { of stores }\end{array}$ & $\begin{array}{l}\text { sales area } \\
\text { in } \mathrm{m}^{2}\end{array}$ & $\begin{array}{l}\text { species } \\
\text { abun- } \\
\text { dance }\end{array}$ & $\begin{array}{c}\text { sales area } \\
\text { in } \mathrm{m}^{2} / 1 \\
\text { store }\end{array}$ & $\begin{array}{c}\text { sales area } \\
\text { in } \mathrm{m}^{2} / 1,000 \\
\text { inhab. }\end{array}$ & $\begin{array}{c}\text { number of } \\
\text { inhabit- } \\
\text { ants } / 1 \\
\text { store }\end{array}$ & $\begin{array}{l}\text { store concen- } \\
\text { tration index }\end{array}$ & $\begin{array}{c}\text { sales area } \\
\text { concentration } \\
\text { index ** }\end{array}$ \\
\hline Bánová & 1,868 & 4 & 134 & 3 & 33.5 & 72 & 467 & -43 & -191 \\
\hline Bôrik & 3,523 & 3 & 150 & 3 & 50.0 & 43 & 1,174 & -123 & -329 \\
\hline Brodno & 1,305 & 3 & 113 & 1 & 37.7 & 87 & 435 & -39 & -157 \\
\hline Budatín & 1,753 & 7 & 473 & 4 & 67.6 & 270 & 250 & -18 & -1 \\
\hline Bytčica & 2,022 & 35 & 7,507 & 11 & 214.9 & 3,713 & 58 & 4 & 61 \\
\hline Hájik & 8,159 & 4 & 965 & 3 & 241.3 & 118 & 2,040 & -221 & -112 \\
\hline Hliny & 11,396 & 120 & 14,022 & 16 & 116.9 & 1,230 & 95 & 0,1 & -2 \\
\hline M. Lúčka & 424 & 1 & 20 & 1 & 20.0 & 47 & 424 & -38 & -296 \\
\hline P. Chlmec & 1,367 & 14 & 1,959 & 8 & 140.0 & 1,433 & 98 & -1 & -1 \\
\hline Rosinky & 911 & 6 & 4,095 & 2 & 682.5 & 4,495 & 152 & -7 & 68 \\
\hline Solinky & 13,266 & 68 & 15,021 & 15 & 221.0 & 1,132 & 195 & -12 & 3 \\
\hline Staré Mesto & 10,851 & 565 & 51,823 & 17 & 91.7 & 4,776 & 19 & 8 & 7 \\
\hline Strážov & 544 & 4 & 2,040 & 3 & 510.0 & 3,750 & 136 & -5 & 62 \\
\hline Trnové & 2,536 & 7 & 414 & 3 & 59.0 & 163 & 362 & -31 & -78 \\
\hline Vlčince & 18,472 & 97 & 18,735 & 16 & 193.0 & 1,014 & 190 & -12 & -4 \\
\hline Vranie & 733 & 1 & 6 & 1 & 6.0 & 8 & 733 & -73 & $-1,753$ \\
\hline Zádubnie & 743 & 1 & 84 & 1 & 84.0 & 113 & 743 & -74 & -118 \\
\hline Zástranie & 939 & 1 & 105 & 1 & 105.0 & 112 & 939 & -96 & -119 \\
\hline Závodie & 2,465 & 10 & 2,879 & 6 & 287.9 & 1,168 & 247 & -18 & -2 \\
\hline Žil.Lehota & 314 & 1 & 78 & 1 & 78.0 & 248 & 314 & -25 & -48 \\
\hline Žilina & 83,591 & 952 & 120,623 & 17 & 126.7 & 1,443 & 88 & & \\
\hline
\end{tabular}

Source: field research, compiled by authors

Note: $C B$ s from the $1^{\text {st }}$ cluster are highlighted red, $C B$ s from the $2^{\text {nd }}$ cluster are highlighted orange and CBs from the $3^{\text {rd }}$ cluster are highlighted green (dark and lights); * the surplus concentration index $\left(I_{C S}\right) x 1,000, * *$ the surplus concentration index $\left(I_{c S}\right)$ sales area $x 1,000$ 
The downtown of the CB Stare Mesto is the multifunctional center with its historic Marian Square. Along with the nine streets coming out of it, it forms the historical core of Žilina. The square has been a market center since its inception, with the seat of the city authorities and the richest burgers and merchants. Near the square is the SC Aupark, the largest shopping center of Žilina (Table 2). The oldest shopping mall in Žilina is PRIOR, opened in 1975 at Andrej Hlinka Square. The retail chain Tesco operated here in 2005 - 2016, and since 2016 it has been owned by SIRS. The dominant feature of this square is SC Mirage, which was open in 2010, the same year as the SC Aupark. Based on evaluated indexes (Figures 4, 5 and 6), the CB Staré Mesto achieves a high level of amenities in the retail network (Figure 7) despite the low sales area of the store $\left(91,7 \mathrm{~m}^{2} / 1\right.$ store $)$, which is a hallmark of historic centers that are made up of a variety of small stores. It reaches a very high level in the sales area saturation index and parameter of inhabitants'number / 1 store.

In the $2^{\text {nd }}$ cluster were included CBs Vlčince, Solinky, and Hliny - the biggest residential CBs of Žilina. The CB Hliny has a 13\% share of the city's stores. The dominant part of them is located on the so-called "Boulevard" (Anton Bernolák Street), which separates residential districts Hliny I. and II. Alongside its length, commercial premises are located on the ground floor of residential buildings. The CB Vlčince has different character. More than half of the stores are concentrated in the SC Atrium Dubeň, which is one of the oldest shopping centers in the city, opened in 2001. Even the CB Solinky is characterized by the concentration of stores in the shopping center SEC (Shopping Entertainment Center) Max. The CBs Vlčince and Solinky reach a high level in the synthetic assessment of the level of retail amenities, however, the CB Hliny only reaches an average level. In the parameter number of inhabitants/1 store, the situation is reversed. The highest level is achieved by the CB Hliny, but the other two CBs from the $2^{\text {nd }}$ cluster also reach a high level. In the sales area saturation index, all three residential CBs reach the same level. In addition to shopping centers with a sales area of over 2,500 $\mathrm{m}^{2}$, the retail amenities structure of the residential CBs is supplemented with food stores and specialized stores - Billa and Tesco in the CB Hliny, Tesco and Lidl in the CB Solinky and Lidl, Kaufland, Billa and Nay Elektrodom in the CBs Vlčince.

A substantial part of the CBs was included in the $3^{\text {rd }}$ cluster. These are city boroughs with rural character and Hájik housing estate. In addition to the residential CB Hájik, the number of inhabitants in these CBs is below the average of the city of Žilina. The residential CB Hájik is close to other residential CBs included in the $2^{\text {nd }}$ cluster but has a significantly smaller network of retail stores. CBs from the $3^{\text {rd }}$ cluster are characterized by fewer stores and their total sales area with values of these indicators below city averages. The only exception is the city district of Bytčica, which exceeded the average value of the sales area by 1476 and with 35 stores it was close to the city average also in the number of retail stores (Table 3). Five CBs (Mojšova Lúčka, Vranie, Zádubnie, Zástranie and Žilinská Lehota) have 1 store, of course, they are food stores.

This cluster is also very varied internally in terms of synthetic evaluation (Figure 7). The CBs reach the level of retail amenities from very low (peripheral CBs Bánová, Brodno, Vranie) to very high (CBs Bytčica, Rosinky, Bytčice, Strážov), which was based on the evaluation of individual indicators. Concerning the size parameter, the CBs with a small sales area per one store are predominant. Above-average levels are characteristic for the CBs Strážov, Rosinky, and Závodie, as well as in the sales area saturation index. The low and very low type of retail amenities in the city have mainly CBs that have retained rural character without the traffic communications of higher grades. In the dendrogram obtained using Ward's method, it is possible to divide the city districts up to three clusters. Clustering can be done earlier in this case, even before the cluster of CBs with the character of rural settlement is merged. This would create two new clusters that are distinguished in Table 3 by dark and light shades of green. The divergence of these clusters is evident in the number of stores and sales area indicators. The CBs with a more intensive retail network, which are approaching the average of Žilina, are highlighted by the darker shade of green. This cluster includes the CBs Hájik, Strážov, Rosinky, Závodie, Považský Chlmec, and Bytčica. The lighter shade highlighted the CBs with a small number of stores and a small sales area. This cluster is made up of ten CBs (Table 3). 


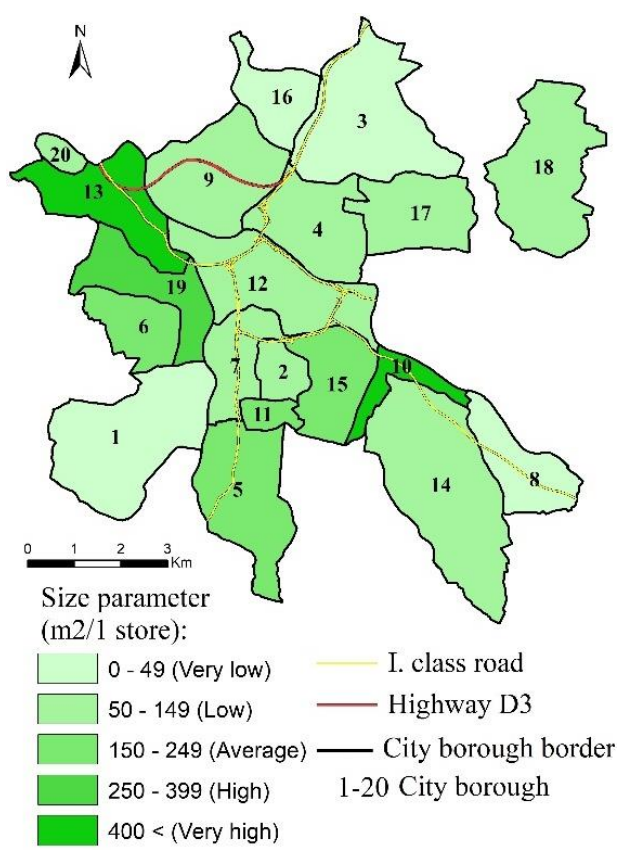

Figure 4. The size parameter of stores of Žilina CBs in 2015;

Source: field research, 2015; CBs numbers: see Fig. 2

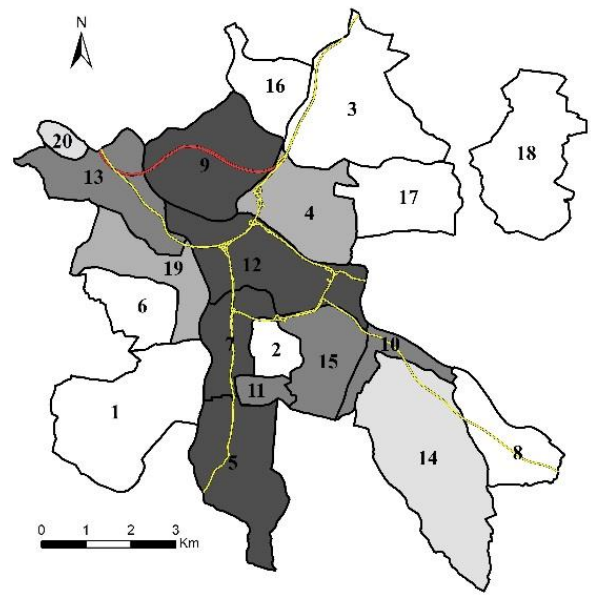

Parameter of inhabitants' number /1store:

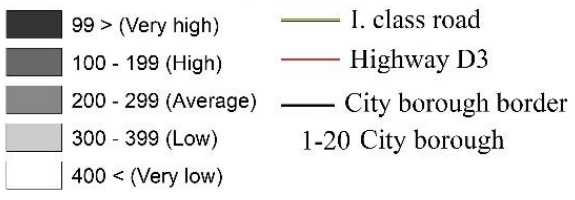

Figure 6. Parameter of inhabitants' number/1 store of Žilina CBs in 2015;

Source: field research, 2015;

CBs numbers: see Fig. 2

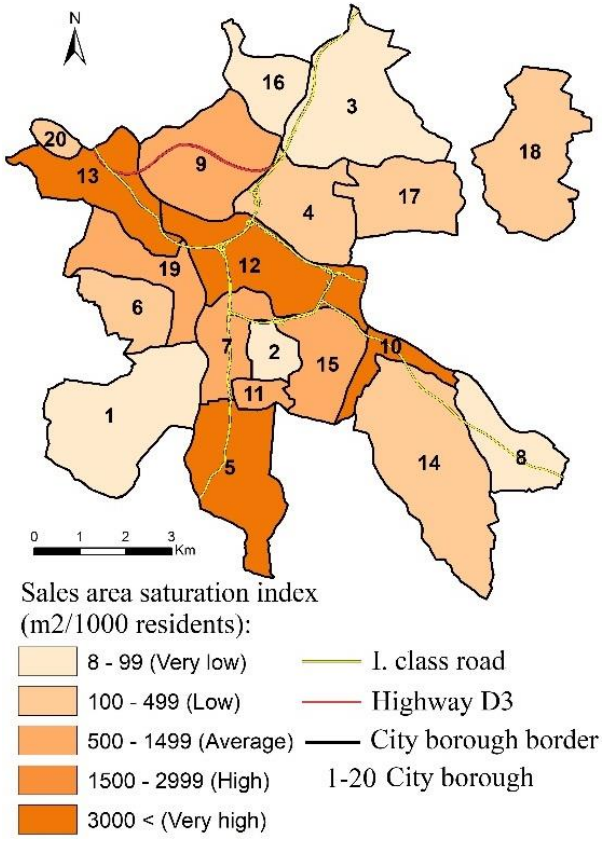

Figure 5. The sales area saturation index of Žilina CBs in 2015;

Source: field research, 2015; CBs numbers: see Fig. 2

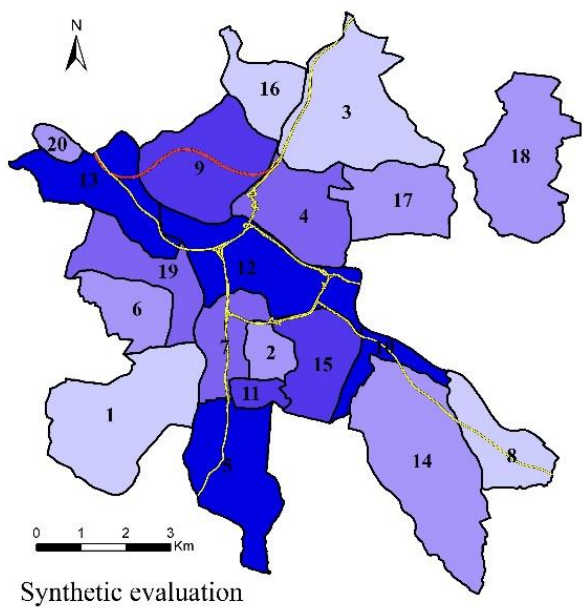
of retail amenity:

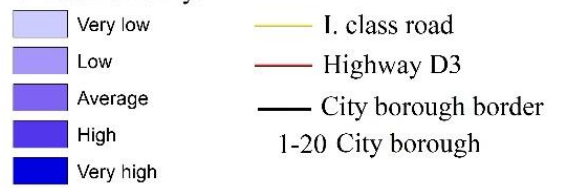

Figure 7. Synthetic evaluation of the retail network of Žilina CBs in 2015;

Source: field research, 2015;

CBs numbers: see Fig. 2 
The assortment structure of retail units is closely related to the number of stores and sales area. The highest variability of stores (from 17 assortment groups) is in the $1^{\text {st }}$ cluster in the CB Staré Mesto. The varied mix of stores is also in the $2^{\text {nd }}$ cluster consisting of the CBs Hliny, Vlčince, and Solinky, mainly made up of brand stores in shopping centers. The CBs with the smallest density of population, retain the rural character with a low assortment structure, represented mainly by food stores.

The results of the cluster analysis point out that the individual CBs in clusters are similar not only to the retail network structure but also to the number of inhabitants. The three-dimensional graph depicting the links between the number of inhabitants, the number of stores and the sales area is shown in Figure 8, which also determines their grouping into clusters.

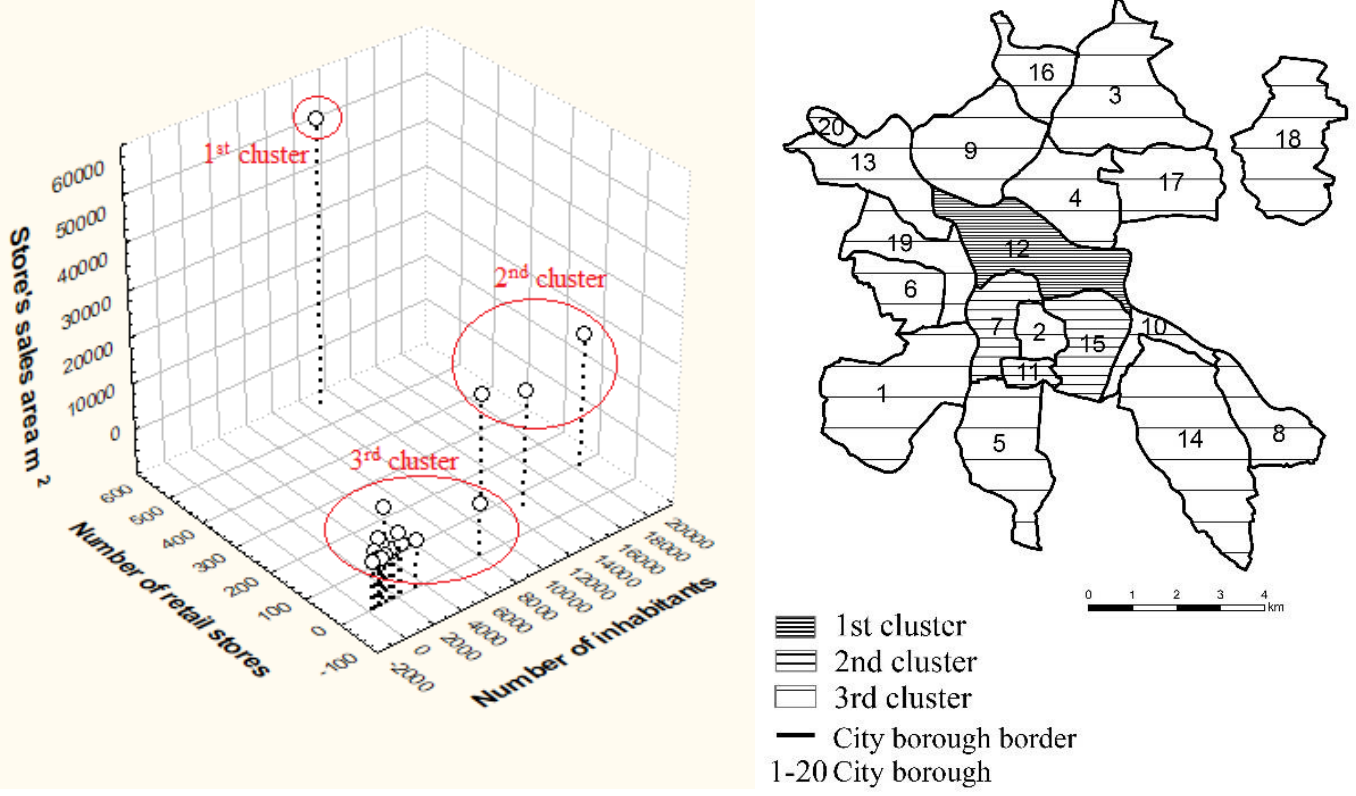

Figure 8. 3D graph and map of retail indicators of the CBs of Žilina; Source: field research, compiled by authors; CBs numbers: see Fig. 2

Relationships between these indicators were evaluated by correlation analysis that was performed for the $2^{\text {nd }}$ cluster and the $3^{\text {rd }}$ cluster. For the $1^{\text {st }}$ cluster, the sample multiple correlation coefficient values could not be calculated because there is only one object. The results are shown in Table 4. In the $2^{\text {nd }}$ cluster, which includes the largest residential CBs of Žilina, there is a perfect degree of a positive association between the sales area and the number of stores and the number of inhabitants in the CB. The full direct dependency of the sales area is also from individual indicators after the impact of the second indicator eliminated. In the CBs from the $3^{\text {rd }}$ cluster, there is a high degree of a positive association between the sales area and the linear combination of the number of stores and the number of inhabitants in the CB. On closer examination, it was found that this high degree of positive association is caused by the association between the sales area and the number of stores after eliminating the impact of the number of inhabitants. This sample partial correlation coefficient is 0,8808 . Between the sales area and the number of inhabitants after eliminating the impact of the number of stores in these CBs, there is a low degree of negative association, with the sample partial correlation coefficient of $-0,0992$. The observed phenomenon is caused by the development of large-scale stores, such as car shops, construction sites, hobby shops, garden stores, etc., in peripheral CBs with good transport accessibility, when the number of inhabitants in the city district is not an important decision factor for the investor, but other factors include, in particular, sufficient suitable and cheap leasable area. 
Table 4. Results of correlation analysis

\begin{tabular}{l|c|c}
\hline & the 2 ${ }^{\text {nd }}$ cluster & the $3^{\text {rd }}$ cluster \\
\hline Sample multiple correlation coefficient $r_{X(Y, Z)}$ & 1 & 0,8809 \\
\hline $\begin{array}{l}\text { Sample partial correlation coefficient after eliminating the } \\
\text { impact of the number of inhabitants } r_{X, Y \cdot Z}\end{array}$ & 1 & 0,8808 \\
\hline $\begin{array}{l}\text { Sample partial correlation coefficient after eliminating the } \\
\text { impact of the number stores } r_{X, Z \cdot Y}\end{array}$ & 1 & $-0,0992$ \\
\hline
\end{tabular}

Source: field research, compiled by authors

The links between the number of stores and the size of the sales area in relation to the population of $\mathrm{CBs}$ and the average population of the city point to a surplus or scarcity of retail facilities in the individual CBs. According to Bilková and Križan (2013), Žilina achieved a surplus in the balance sheet in retail entities in 2010. The store concentration index (Figure 9) and the sales area concentration index (Figure 10) at the level of CBs shows the concentration level from very low to very high. In the CBs Staré Mesto and Bytčica, there is an aboveaverage concentration of retail entities in both indicators. There is also a high concentration of retail stores in the CB Hliny. The high concentration of the sales area is also characteristic of the CBs Solinky and Strážov. In particular, which have surpluses.

\section{Discussion and Conclusions}

The construction of new shopping centers significantly influences the retail life in the historic town centers, changing it in a positive as well as in a negative way. Positively, if pedestrian zones remain "alive", a wide range of small, assorted retail stores, mostly with fashionable, attractive goods, goods not only attracting domestic visitors but mainly tourists are still being developed. The large shopping centers SC Mirage and SC Aupark in the CB Staré Mesto, built on its edge, in the geographic proximity of the historical center, did not cause the disappearance of small stores mainly of Slovak entrepreneurs and did not affect the pedestrian zones very much. Negatively, for example, in the city of Nitra, where the construction of the SC Mlyn led to the withdrawal of more attractive retail stores from the pedestrian zone to the shopping center located at the beginning of the pedestrian zone and thus it is a retail "mortification"(Trembošová and Tremboš, 2016). Attractive retail stores have been replaced mainly by lower product quality stores, various bazaars, secondhands, Chinese stores.

Newly created centers of retail amenities are formed on the outskirts of residential CBs along main roads. These centers of shopping malls with large-scale stores and complex services are easily accessible by car but also by public transport. These CBs accumulate a substantial part of the retail space units as well as the sales area and reach a surplus of size parameter. The lowest level is achieved by the CBs located on the outskirts of the city, with generally lower social amenities, a lower number of inhabitants and rural character. After 1989, the monocentric type of retail network in Žilina was transformed into polycentric, as in most cities in Slovakia.

Based on the research carried out in the regional cities of Nitra, Trnava and in the case of Žilina, several principles of forming a retail network of large cities in Slovakia can be confirmed: - Location and accessibility are of key importance in the construction of large shopping centers. Therefore, it is no coincidence that they are built on vacant parts of CBs or green areas on the outskirts of cities, along important traffic routes. At the same time, it is necessary to provide enough parking space for their operation, which can be extensive and at ground level due to lower land prices in these locations. Banai and Antipova (2016) studied the example of retail stores of two comparable shopping centers located in urban and suburban environments, both owned by the same wholesaler, the impact of the location of the service provided on the retailer's viability. In their view, the viability of the store is mainly influenced by three conditional factors - the physical qualities of the shopping center's built environment, employment, and business activity. 
- The arrival of multinational chains connected with the massive construction of shopping centers and especially in new locations, often "on the greenfield " (SC Atrium Dubeň, SEC Max, SC Aupark and SC Mirage).

- The concentration of large-scale shopping areas. Examples include the CB Vlčince, where several large-scale trading buildings are concentrated in one location (SC Atrium Dubeň, Kaufland, Lidl, NAY Elektrodom, OBI and COOP Jednota).

- The synergic effect of several large-scale retail facilities located in the same location (Wrigley and Lowe 2002), complemented by various types of catering, banking, tourism, sports, etc. services.

- The crucial and specific factor of retail is the local government, which through land-use planning and management tools, tax and fee policies, sales of land, rental rates, etc., can significantly influence not only site selection but (to a lesser extent) some other factors such as availability. The local administration can only decide on the localization of sales units through land-use management, but it has no authority to influence the assortment structure of sales units in objects it does not own (Trembošová and Dubcová 2016). Nevertheless, it is necessary to draw the local government's attention in particular to the emergence of the food desert phenomenon not only in the big cities of Slovakia (Križan and Danielová 2008).

- Competition, fluctuations in the economy, especially the crises, lead to more effective behavior by retailers, according to Lawrence and Kuby (2016), reflected in a number of closed stores and retail chains, as well as in restructuring and renovation of older facilities for new stores. Given these trends, brick and mortar retail store may not be so large in the future, but they will continue to play an important role as they will merge into an overall nationwide experience (Lawrence and Kuby 2016). We can expect this development also in the environment of Žilina.

- Electronization, increasing the electronic literacy of the population, lead, for example, to the change of retail business strategies, e.g. the development of e-shops, the expansion of selfservice cashiers - the cashier without employees in brick and mortar retail stores (Leng and Wee 2016). Electronization is involved in releasing employees and it can be said that it is heading for some dehumanization of retail stores, although Legéň (2017) points out that people will be more important to retail than revolutionary technologies.

- Trends in information technologies will increasingly be reflected in qualitative research, as a retail network formation factor, and will also introduce new forms of sales. The rate of data discovery for research becomes much more complicated / inaccessible and will have to be combined with field research, for example by identifying data on sales area, number of cash desks and parking spaces, etc., by the observation method.

These tendencies confirm that the retail network of Žilina is at the concentration stage, caused by the increase in sales areas and by increasing the profitable minimum size of the sales area, causing the so-called size parameter to increase (Rumpel et al. 2013). As in most cities in Slovakia, a change of the monocentric type with one core in the city center to polycentric with multiple cores can be observed in the development of the retail network after 1989. Retail facilities until 2005 were mainly concentrated in the city center - in the CB Stare Mesto. With the emergence of new growth poles of the retail network, the disparity in retail amenities between individual CBs of Žilina increased. There are differentiation and significant spatial expansion in several locations in the line from northwest to the southeastern part of the city. This process was most marked in the CBs Vlčince, Rosinka, Bystrica and Strážov, which were caused by the transport network of I. and II. classes roads. At present, there are undersized retail amenities in most CBs. The surplus is shown only in two CBs Bytčica and Staré Mesto.

The diversification processes of the retail network of Žilina were influenced mainly by the effort to bring the stores closer to potential customers (SC Atrium Dubeň in the CB Vlčince), fill the "blank spots" in the city center (SC Mirage and SC Aupark in the CB Staré Mesto), 
occupy space and take advantage of increased customer mobility, in case of construction also lower price of land (SEC Max in the CB Solinky). For the newly built large retail facilities, a convenient traffic location was crucial. As in other cities, there is commercial suburbanization of demand causing "sucking" of the purchasing power of city center's inhabitants, thereby logically weakening the spatial link between purchasing and consumption (Rumpel et al. 2013). Commercial suburbanization uses the location of traffic routes to build new facilities (the $\mathrm{CB}$ Bytčica). Shopping parks such as SEC Max, SC Atrium Dubeň, Tesco hypermarket, Billa supermarket, Merkury Market hobby-market on frequented highways towards Poprad and Rajec arose in Žilina.

The retail network of Žilina is already saturated to a large extent with large-scale commercial facilities and their further expansion depends on the bulge and purchasing power of the city's inhabitants. The pressure for further construction is expected to be in the housing development areas, in the outlying areas of the city with favorable traffic accessibility, as well as along the city's major and suburban axes of radial direction. It is anticipated that the expansion of retail network amenities will affect the functional structure of the respective city borough.

New localities are assessed at the level of self-government according to individual decisions of local and municipal councils, currently without regulatory criteria of local retail development planning. The results of the study contribute to the updating of geographic information for local and regional authorities as well as managers of existing and investors of new business facilities. They provide an impetus for further research in the retail segment, including the integration of geographic knowledge, methods and practices.

\section{References}

ALEXANDER, N. 2009: International Retailing. New York (Oxford University).

BANAI, R., ANTIPOVA, A. 2016: Retail-center viability and urban form: a micro analysis. The International Review of Retail, Distribution and Consumer Research. 26(5), 521-540. DOI: https://doi.org/10.1080/09593969.2016.1202855.

BEDNÁ̌̌, P. 2005: Geografie maloobchodní sítě v polycentrickém městě. Acta Facultatis Rerum Naturalium Universitatis Comenianae, Geographica, Supplementum, 3, 30-42.

BILKOVÁ, K., KRIŽAN, F. 2013: Koncentrácia podnikatel'ských subjektov v maloobchode v slovenských mestách. Geographia Cassoviensis, 7(1), 31-44.

BILKOVÁ, K., KRIŽAN, F. 2015: Mapping of grocery stores in Slovak countryside in context of food deserts. Acta Universitatis Agriculturae et Silviculturae Mendelianae Brunensis, 63(5), 1633-1638. DOI: https://doi.org/10.11118/actaun201563051633.

CIVÁŇ, M., SVORAD, A., KROGMANN, A. 2014: Outlet centre as a potential development impulse: a case study of the municipality of Voderady. Mendel Net 2014 : proceedings of International PhD Students Conference, Brno (Mendel University), 340-344.

CHOI, Y., SUZUKI, T. 2013: Food Deserts, Activity Patterns, \& Social Excclusion: The Case of Tokyo, Japan. Applied Geography, 43, 87-98. DOI: https:doi.org/10.1016/j.apgeog. 2013.05.009.

DRGOŇOVÁ, Z. 2016: Geografické aspekty maloobchodnej siete mesta Žilina - diplomová práca. Nitra (UKF).

DRZOG, V. 2004: Versorgung im ländlichen Raum (am Beispiel der weiteren Umgebung der Siedlund Lenart in NO Slowenien). In Neue Einzelhandel-strukturen am Rande von Kleinstädten, Tagung Forschungssechseck Hartberg. Graz (Karl-Franzens Universität), pp. 77-88.

FERTALOVÁ, J. 2005: Regionálno-geografické aspekty hodnotenia vývoja maloobchodu na Slovensku po roku 1989. Folia geographica, 8, 5-12. 
FERTAL'OVÁ, J. 2006: Evaluation of attendance in selected hypermarkets and shopping stores in the towns of Prešov and Košice. Acta Universitatis Palackianae Olomucensis Facultas Rerum Naturalium, Geographica, 39, 19-29.

FERTAL'OVÁ, J., KLAMÁR, R. 2006: Hodnotenie návštevnosti vybraných vel'koplošných predajní. Folia geographica, 10, 140-155.

FLORIAN, M., SCHWARZ, R., ZSILINCSAR, W. 2004: Gleisdorf Rezente Entwicklung im Einzelhandel. In Neue Einzelhandelstrukturen am Rande von Kleinstädten, Tagung Forschungssechseck Hartberg. Graz (Karl-Franzens Universität), 1-14.

GUY, C. 1998: Classifications of Retail Stores and Shopping Centres: Some Methodological Issues. GeoJournal, 45(4), 255-264.

HILLIER, B. 1999: Centrality as a process: Accounting for attraction inequalities in deformed grids. Urban Design International, 4(3-4), 107-127.

JINDRA, J. 1996: Obchodní firmy: mezinárodní retailing. Praha (Vysoká škola ekonomická).

KOTALA, D., BILKOVÁ, K., KUNC, J., TONEV, P. 2017: Omezené možnosti nakupování (nejen) v centru Brna? Identifikace potravinových pouští. Maloobchod a špecifiká časovopriestorového správania spotrebitelov. Eds. Križan, F., Bilková, K., Barlík, P., Bratislava (Univerzita Komenského), 197-228.

KRIŽAN, F. 2007: Regionálna typológia územia Bratislavy na základe dostupnosti supermarketov a hypermarketov. Geografický časopis, 59(4), 373-384.

KRIŽAN, F. 2009: Globalizácia maloobchodu: definícia základných procesov a ich analýza v slovenskej geografii maloobchodu. Geografický časopis, 61(1), 49-68.

KRIŽAN, F., ALFÖLDIOVÁ, M., LAUKO, V. 2008: Vybrané prejavy transformácie terciárneho sektora mesta Galanta po roku 2000. In Klímová, V. ed. XI. Mezinárodní kolokvium o regionálních védách. Brno: Masarykova univerzita, 294-301.

KRIŽAN, F., DANIELOVÁ, K. 2008: „Potravinové púšte“ definované na základe merania dostupnosti - prípadová štúdia mesta Bratislava. Urbanismus a územní rozvoj, 9(3), 1-6.

KRIŽAN, F., KUNC, J., BILKOVÁ, K., BARLÍK, P., ŠILHAN, Z. 2016: Development and classification of shopping centres in Czech and Slovak republic: A comparative analysis. Acta Universitatis Carolinae Geographica, 52(1), 18-26. DOI: https:doi.org/10.14712/23361980.2017.2.

KUNC, J., SZCZYRBA, Z., FRANTÁL, B., TONEV, P. 2012: Nákupní spád, nákupní chování a nákupní centra: př́klad brněnské aglomerace (příspěvek ke studiu denních urbánních systémů). Sociologický časopis, 48(5), 879-910. Retrieved from: https:// Www.jstor.org/stable/i23534884.

LAWRENCE, J., KUBY, M. 2016: The Location Types of US Retailers. International Journal of Applied Geospatial Research, 7(4), 1-22. DOI: https://doi.org/10.4018/IJAGR2016100101.

LEGÉŇ, M. 2017: L’udia budú pre retail dôležitejší ako prevratné technológie. Trend : týždennik o ekonomike a podnikani. Bratislava: News and Media Holding, 28(27), 44-45.

MARKECHOVÁ, D., STEHLÍKOVÁ, B., TIRPÁKOVÁ, A. 2011: Štatistické metódy a ich aplikácie. Nitra (Univerzita Konštantína Filozofa v Nitre).

MARYÁŠ, J., KUNC, J., TONEV, P., SZCZYRBA, Z. 2014: Shopping and services related travel in the hinterland of Brno: changes from the socialist period to the present. Moravian Geographical Reports, 22(3), 18-28. DOI: https://doi.org/10.2478/mgr-2014-0015.

MITRÍKOVÁ, J. 2008: Geografické aspekty transformácie maloobchodu a nákupného správania sa na Slovensku (prípadové štúdie z miest Prešov a Košice). Prešov (Prešovská univerzita).

MITRÍKOVÁ, J. 2017: Geografia maloobchodu (vybrané kapitoly). Prešov (Prešovská univerzita).

MULÍČEK, O. 2007: Prostorové aspekty současného vývoje brněnské maloobchodní sítě. $U r$ banizmus a územní rozvoj, 8(1), 14-20. 
NAGY, E. 1999: Fall and Revival of City Centre Retailing: Planning an Urban Function in Leicester, Britain. Pécs (Centre for Regional Studies).

NAGYOVÁ, L'. 2000: Zmeny na slovenskom trhu potravín v dôsledku vstupu zahraničných obchodných sietí. Zbornik z medzinárodnej konferencie „Ekonomika firiem 2000“. Košice, Podnikovohospodárska fakulta Ekonomická univerzita, 451-456.

OČOVSKÝ, Š. 1976: Vybrané problémy štúdia nákupných miest. Geografický časopis, 28(1), 23-36.

OC ATRIUM DUBEŇ ŽILINA 2016: Oficiálna stránka OC ATRIUM DUBEŇ [cit. 2016-0220]. Retrieved from: https://www.atrium-duben.sk/.

OC AUPARK ŽILINA 2016: Oficiálna stránka OC AUPARK Žilina [cit. 2016-02-20]. Retrieved from: https://www.auparkzilina.sk/

OC MIRAGE ŽILINA 2016: V Žiline s rozpakmi otvárajú nové nákupné centrá. [cit. 201602-20]. Retrieved from: https://www.living.sk/

SUCHÝ, J. 2010: Problematika potravinových pouští - př́padová studie Zlín. Diplomová práce. Praha: Katedra sociální geografie a regionálního rozvoje PřF UK, $83 \mathrm{~s}$.

SZCZYRBA, Z. 2001: Funkční vztahy v maloobchodní vybavenosti města Olomouce. Folia geographica, 35, 205-213.

SZCZYRBA, Z. 2005: Maloobchod v $\check{C} R$ po roce 1989. Vývoj a trendy se zaměrením na geografickou organizaci. Olomouc (Univerzita Palackého).

SZCZYRBA, Z. 2006: Geografie obchodu - se zaměrením na současné trendy v maloobchodè. Olomouc (Univerzita Palackého).

SZCZYRBA, Z., FIEDOR, D. 2014: Vývoj velkoplošného maloobchodu Olomouce a výzkum nákupního chování. In Klimová, V. ed. 17th International Colloquium on Regional Sciences. Brno (Masaryk university), pp. 740-748. DOI: https:doi.org/10.5817/CZ.MUNI.P210-6840-2014-96.

TREMBOŚOVÁ, M. 2009: Nitra - mesto obchodných centier. Geografické štúdie, 13(1), 69-79.

TREMBOŠOVÁ, M. 2010: Vybrané aspekty transformácie maloobchodu v meste Nitra v rokoch 1992 - 2008. Geografický časopis, 62(1), 49-73.

TREMBOŠOVÁ, M. 2012: Geografické aspekty maloobchodnej siete mesta Nitra. Nitra (Univezita Konštantína Filozofa).

TREMBOŠOVÁ, M., DUBCOVÁ, A. 2013: Vývoj maloobchodu v Nitre v nových trhových podmienkach. Acta Geographica Universitatis Comenianae, 57(2), 213-230.

TREMBOŠOVÁ, M., DUBCOVÁ, A. 2016: Atraktivita maloobchodnej vybavenosti podl'a obyvatel'ov vybraných mestských častí $\mathrm{v}$ meste Nitra. XIX. mezinárodní kolokvium o reionálních vědách. Brno (Masarykova Univerzita), pp. 537-545. DOI: https:doi.org/10.5817/CZ.MUNI. P210-8273-2016-69.

TREMBOŠOVÁ, M., DUBCOVÁ, A., CIVÁŇ, M. 2016a: Geografické aspekty maloobchodnej siete mesta Trnava a nákupné správanie jej obyvatel'stva. Nitra (Univerzita Konštantína Filozofa).

TREMBOŠOVÁ, M., DUBCOVÁ, A., KRAMÁREKOVÁ, H., NAGYOVÁ, L'. 2016b: Nákupné správanie obyvatel'stva mesta Nitry, vývoj a zmeny. Nitra (Slovenská pol'nohospodárska univerzita).

TREMBOŠOVÁ, M., CIVÁŇ, M., DUBCOVÁ, A., KRAMÁREKOVÁ, H. 2016c: Retail Network and Perspectives (Introduction into the Issues). In Lňenička, L. ed. Central Europe Area in View of Current Geography: Proceedings of 23rd Central European Conference. Brno (Masarykova Univerzita), 292-300. DOI: https:doi.org/10.5817/CZ.MUNI. P210-8314-2016.

TSENKOVA, S. 2014: Planning trajectories in post-socialist cities: patterns of divergence and change". Urban Research \& Practice, 7 (3), 278-301. DOI: https://doi.org/10.1080/ 17535069.2014.966513 
VITKOVÁ, L'. 2001: Urbanistická ekonómia ako faktor územného rozvoja. Bratislava (Slovenská technická univerzita).

VRÁBELOVÁ, M. 2013: Multivariačné analýzy údajov. Nitra (Univerzita Konštantína Filozofa $v$ Nitre).

WRIGLEY, N., WARM, D., MARGETTS, B. 2003: Deprivation, Diet, and Food-Retail Access: Findings from the Leeds 'Food Deserts' Study. Environment and Planning A, 35, 151188. DOI: https://doi.org/10.1068/a35150.

ZOC MAX ŽILINA. 2016: Oficiálna stránka ZOC MAX Žilina. [cit. 2016-02-20]. Retrieved from: https://www.zoc-max.sk/zilina/.

This work was supported by the Slovak Research and Development Agency under the Contract No. APVV-18-0185.

Authors ' affiliations

RNDr. Miroslava Trembošová, PhD.

Katedra geografie a regionálneho rozvoja

Fakulta prírodných vied

Univerzita Konštantína Filozofa v Nitre

Tr. A. Hlinku 1

94974 Nitra

Slovakia

mtrembosova@ukf.sk

Doc. RNDr. Alena Dubcová, CSc.

Katedra geografie a regionálneho rozvoja

Fakulta prírodných vied

Univerzita Konštantína Filozofa v Nitre

Tr. A. Hlinku 1

94974 Nitra

Slovakia

adubcova@ukf.sk

Mgr. Michaela Štubňová

Ústav ekonomiky a manažmentu

Fakulta prírodných vied

Univerzita Konštantína Filozofa v Nitre

Tr. A. Hlinku 1

94974 Nitra

Slovakia

mstubnova@ukf.sk 